\title{
Transient Studies of Oxygen Removal Pathways and Catalytic Redox Cycles during NO Decomposition on $\mathrm{Cu}-\mathrm{ZSM5}$
}

\author{
Björn Modén, Patrick Da Costa, Deuk Ki Lee, ${ }^{\dagger}$ and Enrique Iglesia* \\ Department of Chemical Engineering, University of California at Berkeley, Berkeley, California 94720
}

Received: March 15, 2002; In Final Form: June 18, 2002

\begin{abstract}
The identity of reactive intermediates and of active sites and the details of redox cycles and oxygen removal pathways during NO decomposition on well-characterized $\mathrm{Cu}-\mathrm{ZSM} 5$ were examined by combining previous spectroscopic and steady-state kinetic studies with measurements of the rate of evolution of $\mathrm{NO}_{2} \mathrm{~N}_{2} \mathrm{O}, \mathrm{NO}_{2}$, $\mathrm{N}_{2}$, and $\mathrm{O}_{2}$ during isothermal and nonisothermal kinetic transients. The oxygen coverages measured during reversible isothermal switches from $\mathrm{He}$ to $\mathrm{NO} / \mathrm{He}$ mixtures showed that $\mathrm{NO}$ decomposition involves bimolecular reactions of two $\mathrm{NO}$ molecules adsorbed on vicinal $\mathrm{Cu}^{+}$species with the formation of $\mathrm{N}_{2} \mathrm{O}$ as the initial product near ambient temperature. These vicinal $\mathrm{Cu}^{+}$species form via oxygen removal from $\left\{\mathrm{Cu}^{2+}-\mathrm{O}^{2-}-\mathrm{Cu}^{2+}\right\}^{2+}$ to form $\left\{\mathrm{Cu}^{+}-\square-\mathrm{Cu}^{+}\right\}^{2+}$ using $\mathrm{NO}_{2}$ as an oxygen carrier among distant oxidized dimers. Adsorbed nitrate $\left(\mathrm{NO}_{3}{ }^{*}\right)$ is the kinetically relevant intermediate in the formation of $\mathrm{O}_{2}$ during $\mathrm{NO}$ decomposition. This $\mathrm{NO}_{3} *$ decomposition reaction is one of the steps involved in the equilibrated formation of $\mathrm{NO}_{2}$ observed during $\mathrm{NO}$ decomposition. These NO-mediated oxygen removal pathways, in which NO acts both as a reductant and as an oxidant, are significantly more rapid than recombinative desorption steps. The desorption of products and of unreacted NO during reactions of preadsorbed NO with increasing catalyst temperature confirmed the bimolecular nature and the low activation energy for $\mathrm{N}_{2} \mathrm{O}$ formation from NO. The facile nature of this reaction and the unfavorable $\mathrm{NO}$ adsorption thermodynamics as temperature increases combine to give the observed decrease in NO decomposition rates at high temperatures. These findings are consistent with some reported mechanism-based steady-state rate expressions and with previous infrared detection of the reaction intermediates proposed here based on isothermal and nonisothermal transients. These pathways appear to be relevant also to $\mathrm{N}_{2} \mathrm{O}$ decomposition reactions, which occur after the initial formation of $\mathrm{N}_{2} \mathrm{O}$ from $\mathrm{NO}$ and involve reactions of $\mathrm{N}_{2} \mathrm{O}$ with $\left\{\mathrm{Cu}^{+}-\square-\mathrm{Cu}^{+}\right\}^{2+}$ and removal of oxygen via NO-mediated desorption pathways. This study brings consensus and some clarification into the mechanistic details for $\mathrm{NO}$ and $\mathrm{N}_{2} \mathrm{O}$ decomposition reactions and resolves some remaining discrepancies and some contradictory conclusions in previous reports.
\end{abstract}

\section{Introduction}

Direct decomposition of $\mathrm{NO}$ to $\mathrm{N}_{2}$ and $\mathrm{O}_{2}$ remains potentially attractive for $\mathrm{NO}_{x}$ removal from combustion streams because reaction thermodynamics are favorable and no sacrificial reductants are required. Catalytic NO decomposition rates, however, are currently too low for practical use. $\mathrm{Cu}$-exchanged ZSM5 zeolites are among the most active NO decomposition catalysts. ${ }^{1-5}$ Several studies have addressed the reaction pathways leading to $\mathrm{N}-\mathrm{N}$ and $\mathrm{O}-\mathrm{O}$ bond formation during $\mathrm{NO}$ decomposition on $\mathrm{Cu}-\mathrm{ZSM} 5$. $^{6-26}$

$\mathrm{Cu}$ is present in $\mathrm{Cu}-\mathrm{ZSM} 5$ as divalent cations after exchange and thermal treatment in air. The predominant $\mathrm{Cu}$ species are isolated $\mathrm{Cu}^{2+}$ cations and $\left\{\mathrm{Cu}^{2+}-\mathrm{O}^{2-}-\mathrm{Cu}^{2+}\right\}^{2+}$ dimers, each interacting with two exchange sites. ${ }^{27} \mathrm{CuO}$ particles can also form in these samples, depending on the synthesis method, ${ }^{6}$ but they were not detected in the samples used in the present study. $\mathrm{Cu}$ dimers have been proposed as the active species in NO decomposition. ${ }^{5-7}$ In contrast with isolated $\mathrm{Cu}^{2+}$ cations, these dimers contain a removable oxygen atom; as a result, they can

* To whom correspondence should be addressed. Telephone: (510) 642 9673. Fax: (510) 642-4778. E-mail: iglesia@cchem.berkeley.edu.

$\dagger$ Permanent address: Division of Civil and Environmental Engineering, Kwangju University, Kwangju 503-703, Korea.

10.1021/jp020731g CCC: \$22.00 undergo the redox cycles implicated in NO decomposition turnovers.

We have previously reported steady-state kinetic rate data for NO decomposition and a consistent set of elementary steps. ${ }^{26}$ These elementary steps replace previously proposed oxygen removal pathways, which require recombinative desorption of nonvicinal oxygens, with a catalytic $\mathrm{NO}-\mathrm{NO}_{2}$ cycle that forms $\mathrm{O}_{2}$ using oxygen atoms in nonvicinal $\left\{\mathrm{Cu}^{2+}-\mathrm{O}^{2-}-\mathrm{Cu}^{2+}\right\}^{2+}$ dimers. This catalytic sequence accounts for the unusual decrease in NO decomposition rates observed above $773 \mathrm{~K}^{3,8,26}$ At lower temperatures, $\mathrm{O}_{2}$ inhibits $\mathrm{NO}$ decomposition rates because of competitive adsorption of oxygen and NO on reduced $\mathrm{Cu}^{+}$sites. This inhibition leads to the normal Arrhenius behavior prevalent below $773 \mathrm{~K}$. At these temperatures, $\mathrm{O}_{2}$ inhibition effects become less severe, $\left\{\mathrm{Cu}^{+}-\square-\mathrm{Cu}^{+}\right\}^{2+}$ species become the most abundant surface intermediates, and the adsorption of NO on such species becomes thermodynamically unfavored. This leads to the decrease in NO decomposition rates observed at higher temperatures.

Isothermal transient studies of $\mathrm{NO}$ decomposition on $\mathrm{Cu}-$ ZSM5 have been previously reported. ${ }^{9-12}$ In these measurements, an inert flow is replaced with a stream containing NO. $\mathrm{N}_{2}$ formation rates are initially high, but they decrease as the system approaches steady state. ${ }^{9-11} \mathrm{O}_{2}$ evolution rates are 
TABLE 1: Elemental Composition and Cu Speciation

\begin{tabular}{lccc}
\hline & $\mathrm{Cu}(0.36)^{a}$ & $\mathrm{Cu}(0.58)$ & $\mathrm{Cu}(0.60)$ \\
\hline $\mathrm{Cu}(\mathrm{wt} \%)$ & 2.25 & 3.31 & 3.88 \\
$\mathrm{Si} / \mathrm{Al}$ & 14.0 & 15.0 & 14.0 \\
$\mathrm{Cu}$ & 0.56 & 0.70 & 0.78
\end{tabular}

${ }^{a}$ Atomic $\mathrm{Cu} / \mathrm{Al}$ ratio. ${ }^{b}$ Measured from the $\mathrm{CO}_{2}$ produced during COTPR after $\mathrm{O}_{2}$ treatment. ${ }^{27}$

initially lower than $\mathrm{N}_{2}$ formation rates, but they increase to the equimolar reaction stoichiometry at steady state. The subsequent removal of $\mathrm{NO}$ from an inert stream leads to initial $\mathrm{O}_{2}$ evolution rates exceeding those measured during steady-state NO decomposition. This has led to the proposal that $\mathrm{NO}$ stabilizes adsorbed oxygen in the form of a $\mathrm{Cu}^{2+}(\mathrm{O})(\mathrm{NO})\left(\mathrm{NO}_{2}\right)$ species. ${ }^{11}$

In situ infrared studies coupled with mass spectrometry have been used to detect adsorbed species during isothermal NO transients. ${ }^{12}$ The introduction of $\mathrm{NO}$ at $673 \mathrm{~K}$ led to the immediate appearance of a band assigned to $\mathrm{Cu}^{+}(\mathrm{NO})$, and then to a band for bridging $\mathrm{Cu}^{2+}-\left(\mathrm{NO}_{3}{ }^{-}\right)-\mathrm{Cu}^{2+} .12$ These were the only infrared bands detected at $673 \mathrm{~K}$. Infrared studies have also confirmed that $\mathrm{NO}$ adsorbs on $\mathrm{Cu}^{+5,13-18}$ and suggested that $\mathrm{Cu}^{+} / \mathrm{Cu}^{2+}$ redox reactions occur as conditions change from reducing to oxidizing. ${ }^{19}$

NO decomposition appears to occur via the initial formation of $\mathrm{N}_{2} \mathrm{O}$ followed by its decomposition. ${ }^{26} \mathrm{~N}_{2} \mathrm{O}$ and small amounts of $\mathrm{N}_{2}$ are typically detected during temperature-programmed desorption of preadsorbed $\mathrm{NO}$ on $\mathrm{Cu}-\mathrm{ZSM} 5 .{ }^{10,12,20-23}$ Two low-temperature $\mathrm{N}_{2} \mathrm{O}$ desorption peaks and one $\mathrm{O}_{2}$ evolution peak at higher temperatures have been detected along with broader $\mathrm{NO}$ desorption peaks over a wide range of temperature $(300-750 \mathrm{~K}) .{ }^{20}$ Oxidation of the sample before NO adsorption markedly decreased the amount of $\mathrm{N}_{2} \mathrm{O}$ formed. ${ }^{20}$

Here, we report isothermal and nonisothermal transient experiments carried out in the presence and absence of NO in the carrier gas in order to confirm the details of the elementary steps proposed previously based on steady-state kinetic data. ${ }^{26}$ These experiments are then brought together with these steadystate kinetic data and with detailed structural characterization and reduction studies of the $\mathrm{Cu}$ species in these materials. ${ }^{27}$ We conclude with a model of the site requirements and the mechanism of NO decomposition on $\mathrm{Cu}$-ZSM5.

\section{Experimental Methods}

Catalyst Synthesis and Characterization. The synthesis of the $\mathrm{Cu}-\mathrm{ZSM} 5$ catalysts and the characterization of their structure and reduction properties have been described in detail elsewhere. ${ }^{27}$ Elemental analyses are shown in Table 1 for all catalysts used in this study. All samples are denoted as $\mathrm{Cu}(x)$, where $x$ is the atomic $\mathrm{Cu} / \mathrm{Al}$ ratio. The $\mathrm{Cu}_{\text {dimer }} / \mathrm{Cu}_{\text {total }}$ ratio represents the fraction of the total $\mathrm{Cu}$ atoms that are present in $\mathrm{Cu}$ dimers.

Reactant and Treatment Gas Mixtures. The NO-containing stream contained $1.00 \% \mathrm{NO}, 9.98 \% \mathrm{Ar}$, and $89.02 \% \mathrm{He}$ (Matheson; <10 ppm impurities). Ar was included as an internal standard for mass spectrometric analyses. The $\mathrm{O}_{2}$ stream consisted of $50 \% \mathrm{O}_{2} / \mathrm{He}$ (Matheson); it was purified by passing through a 13X molecular sieve at ambient temperature. Helium (UHP, Bay Airgas) was used as a diluent for both $\mathrm{O}_{2}$ and NO streams and as an inert carrier gas in transient and desorption experiments. Helium was purified by passage through a $13 \mathrm{X}$ molecular sieve and an oxygen trap (Matheson). The mass spectrometer was calibrated for $\mathrm{N}_{2}, \mathrm{O}_{2}$, and $\mathrm{N}_{2} \mathrm{O}$ using a mixture containing $0.05 \% \mathrm{~N}_{2}, 0.05 \% \mathrm{O}_{2}, 0.05 \% \mathrm{~N}_{2} \mathrm{O}, 10 \% \mathrm{Ar}$, and
$89.85 \% \mathrm{He}$ (Praxair) and for $\mathrm{NO}_{2}$ using another mixture containing $0.05 \% \mathrm{NO}_{2}, 10 \% \mathrm{Ar}$, and $89.95 \% \mathrm{He}$ (Praxair).

Mass Spectrometric Analysis of Reactant and Product Streams. Reactants and product streams were analyzed using on-line mass spectrometry (MKS Instruments, Orion Compact Residual Gas Analyzer) and a differentially pumped atmospheric sampling system (Pfeiffer, vacuum system TCP015, turbomolecular pump Model TMU065). He (4 amu), $\mathrm{N}_{2}$ (28 amu), NO (30 amu), $\mathrm{O}_{2}$ (32 amu), $\mathrm{Ar}$ (40 amu), $\mathrm{N}_{2} \mathrm{O}$ (44 amu), and $\mathrm{NO}_{2}$ (46 $\mathrm{amu})$ were monitored continuously with a time resolution of $2 \mathrm{~s}$ for the isothermal transient experiments, for which high time resolution was required, and $10 \mathrm{~s}$ for other experiments. In all figures, products detected only in trace amounts are not reported.

Sample Treatment Protocols. All $\mathrm{Cu}-\mathrm{ZSM} 5$ samples in this study were treated in either oxidative or nonoxidative environments before transient experiments. The oxidative treatment consisted of contact with $50 \% \quad \mathrm{O}_{2} / \mathrm{He}$ at $5.33 \mathrm{~cm}^{3} \quad(\mathrm{~g}$ of catalyst $)^{-1} \mathrm{~s}^{-1}$ as the temperature was increased at $0.167 \mathrm{~K} \mathrm{~s}^{-1}$ to $773 \mathrm{~K}$. The sample was held at $773 \mathrm{~K}$ for $2 \mathrm{~h}$, and was then cooled slowly to ambient temperature. After reaching ambient temperature, the $\mathrm{O}_{2} / \mathrm{He}$ stream was replaced with $16.7 \mathrm{~cm}^{3}(\mathrm{~g}$ of catalyst $)^{-1} \mathrm{~s}^{-1} \mathrm{He}$ in order to remove weakly adsorbed $\mathrm{O}_{2}$. Helium was used for the nonoxidative treatment. The flow rates and temperature profile were identical to those for the $\mathrm{O}_{2} / \mathrm{He}$ treatment, except that He was used as the carrier gas instead of $50 \% \mathrm{O}_{2} / \mathrm{He}$.

Isothermal Transients. Isothermal transient measurements consisted of rapid switches between $\mathrm{He}$ and NO-containing streams with various NO concentrations. These experiments were carried out using a system designed to minimize hydrodynamic delays. The mean mixing time for a step change in NO concentration was $<10 \mathrm{~s}$ at a flow rate of $1.67 \mathrm{~cm}^{3} \mathrm{~s}^{-1}$.

Temperature-Programmed Desorption (TPD) Studies. NO was adsorbed on $\mathrm{Cu}-\mathrm{ZSM} 5$ (0.3 g) by contacting catalyst samples with $1 \% \mathrm{NO}\left(1.67 \mathrm{~cm}^{3} \mathrm{~s}^{-1}\right)$ for $900 \mathrm{~s}$ at ambient temperature, after treating the samples in either $\mathrm{He}$ or $50 \% \mathrm{O}_{2} /$ $\mathrm{He}$, as described above. After adsorption, the NO stream was replaced with $\mathrm{He}\left(1.67 \mathrm{~cm}^{3} \mathrm{~s}^{-1} ; 0.5 \mathrm{~h}\right)$ at ambient temperature in order to desorb weakly bound species. The temperature was then increased from ambient temperature to $823 \mathrm{~K}$ at $0.167 \mathrm{~K}$ $\mathrm{s}^{-1}$. Temperature-programmed desorption of adsorbed oxygen was performed by treating the catalyst in $50 \% \mathrm{O}_{2} / \mathrm{He}$, and then heating at $0.167 \mathrm{~K} \mathrm{~s}^{-1}$ from ambient temperature to $1100 \mathrm{~K}$ in $1.67 \mathrm{~cm}^{3} \mathrm{~s}^{-1} \mathrm{He}$.

Desorption and Decomposition of Adsorbed NO Using NO-containing Carrier Gas. NO desorption and decomposition rates were measured on $\mathrm{Cu}-\mathrm{ZSM} 5(\mathrm{Cu} / \mathrm{Al}=0.58 ; 0.3 \mathrm{~g})$ as a function of temperature during continuous NO flow. NO $(0.464 \% \mathrm{NO} / \mathrm{He})$ was introduced at $1.67 \mathrm{~cm}^{3} \mathrm{~s}^{-1}$ after treatment in $50 \% \mathrm{O}_{2} / \mathrm{He}$, and the sample temperature was increased to $923 \mathrm{~K}$ at $0.167 \mathrm{~K} \mathrm{~s}^{-1}$.

\section{Results and Discussion}

This study attempts to probe mechanistic details of NO decomposition and the nature of the active intermediates and of the sites required for kinetically relevant steps using a combination of isothermal transient and temperature-programmed rate measurements. The various species likely to exist on $\mathrm{Cu}$ sites during $\mathrm{NO}$ decomposition are shown schematically in Figure 1, where $*$ denotes a reduced $\mathrm{Cu}$ dimer $\left\{\mathrm{Cu}^{+}-\square^{-}\right.$ $\left.\mathrm{Cu}^{+}\right\}^{2+}$. Nitrate species have been detected by infrared spectroscopy; they appear to be the most stable N-containing adsorbed species on $\mathrm{Cu}-\mathrm{ZSM} 5$ during NO decomposition. ${ }^{12,18}$ 


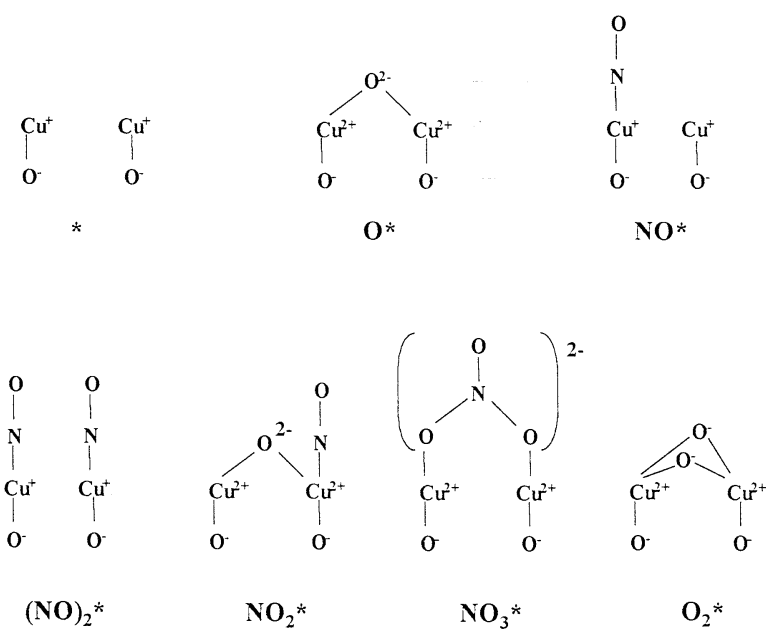

Figure 1. $\mathrm{Cu}$ dimer species on two $\mathrm{Al}$ sites (represented by $\mathrm{O}^{-}$) and adsorbed species proposed to exist on such $\mathrm{Cu}$ dimers during catalytic NO decomposition on $\mathrm{Cu}-$ ZSM5.

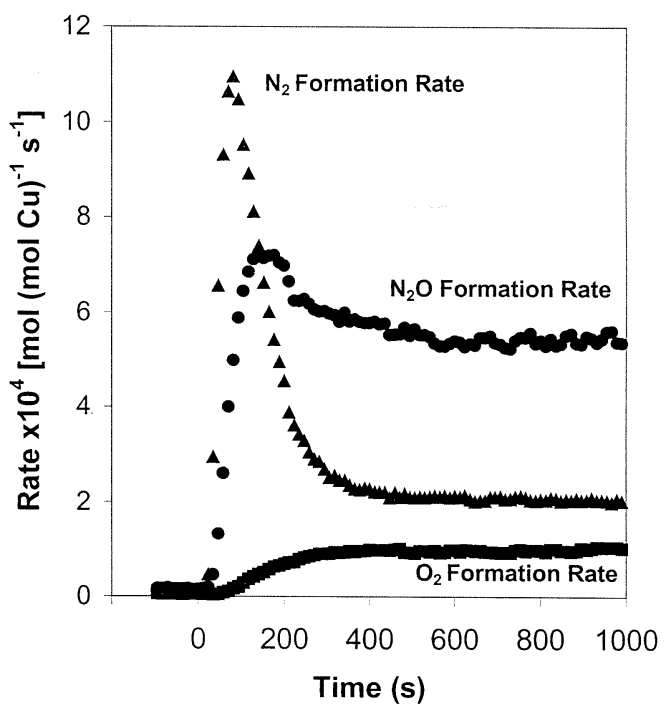

Figure 2. $\mathrm{N}_{2}, \mathrm{O}_{2}$, and $\mathrm{N}_{2} \mathrm{O}$ formation rates during an isothermal switch from pure $\mathrm{He}$ to $1 \% \mathrm{NO}$ at $623 \mathrm{~K}\left[\mathrm{Cu}(0.36), 0.1 \mathrm{~g}, 1.67 \mathrm{~cm}^{3} \mathrm{~s}^{-1}\right.$ total flow rate].

Different forms of adsorbed $\mathrm{NO}_{3}$ and $\mathrm{NO}_{2}$ species have been proposed, but the exact structure of these species is beyond the scope of this study, in which we are concerned only with the stoichiometry and reactivity of such species.

NO Decomposition during Isothermal Transients. The evolution of products after a rapid switch from $\mathrm{He}$ to NOcontaining streams can be used to measure the oxygen content and the concentration of reaction intermediates in each sample as it approaches the catalytic steady state. In contrast with temperature-programmed experiments, in which both the surface coverage of intermediates and the value of the kinetic parameters change during the experiment, only the former varies during isothermal transients.

Isothermal NO decomposition transient data at 623 and 773 $\mathrm{K}$ are shown in Figures 2 and 3, respectively. Between these two temperatures, NO decomposition rates change their temperature dependence from their normal increase with temperature to a decrease in rate with increasing temperature above $\sim 723$ $\mathrm{K}$; these changes in temperature response are likely to reflect changes in the identity of the most reactive surface intermediates. $^{28}$ Thus, it is useful to contrast the catalytic behavior exhibited by $\mathrm{Cu}-\mathrm{ZSM} 5$ at these two temperatures.

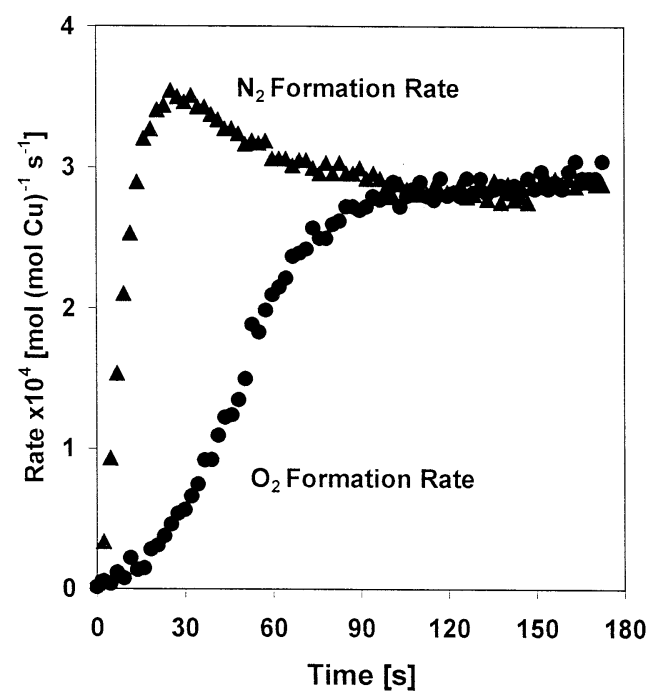

Figure 3. $\mathrm{N}_{2}$ and $\mathrm{O}_{2}$ formation rates during an isothermal switch from pure $\mathrm{He}$ to $0.464 \% \mathrm{NO}$ at $773 \mathrm{~K}\left[\mathrm{Cu}(0.36), 0.1 \mathrm{~g}, 1.67 \mathrm{~cm}^{3} \mathrm{~s}^{-1}\right.$ total flow rate].

Below $673 \mathrm{~K}, \mathrm{NO}_{3}$ * is likely to be present at high surface coverages, ${ }^{12,18}$ while $\mathrm{O} *$ and $*$ are expected to become the most abundant surface intermediates at higher temperatures. Immediately after the step change from $\mathrm{He}$ to $\mathrm{NO}, \mathrm{N}_{2}$ and $\mathrm{N}_{2} \mathrm{O}$ evolution rates increased sharply and then decreased (Figure 2 ). The rate of appearance of products with excess $\mathrm{N}$-atoms $\left(\mathrm{N}_{2}\right.$ and $\mathrm{N}_{2} \mathrm{O}$; relative to the equimolar ratio in $\mathrm{NO}$ ) exceeds that for the formation of products with excess $\mathrm{O}$-atoms $\left(\mathrm{O}_{2}\right.$ and $\mathrm{NO}_{2}$ ) (Figures 2 and 3). This imbalance reflects the net retention of oxygen by $\mathrm{Cu}-\mathrm{ZSM} 5$ during the initial stages of $\mathrm{NO}$ decomposition. $\mathrm{N}_{2}$ and, at lower temperatures, $\mathrm{N}_{2} \mathrm{O}$ are initially formed at rates higher than their steady-state values. This indicates that the accumulation of oxygen, as $\mathrm{O}^{*}, \mathrm{NO}_{2}{ }^{*}$, or $\mathrm{NO}_{3} *$, titrates the active sites required for $\mathrm{NO}$ chemisorption and for decomposition turnovers and inhibits the rate of $\mathrm{N}_{2}$ and $\mathrm{N}_{2} \mathrm{O}$ formation steps. As the surface oxygen content increases with time elapsed after the switch, the rate of $\mathrm{O}_{2}$ formation concurrently increases and the $\mathrm{O}$ and $\mathrm{N}$ imbalance ultimately disappears.

At $773 \mathrm{~K}$, the maximum $\mathrm{N}_{2}$ formation rates measured after the switch are closer to their corresponding steady-state values than in similar experiments at $623 \mathrm{~K}$ (cf. Figures 2 and 3). This indicates a weaker inhibition of NO decomposition rates by oxygen-rich adsorbed species at higher temperatures. In effect, a smaller amount of surface oxygen is retained by the surface as NO decomposition rates reach steady-state values at $773 \mathrm{~K}$ than at $623 \mathrm{~K}$. This is consistent with the lower expected coverages of adsorbed oxygen species $\left[\Theta_{\mathrm{O}}\right.$, mol of $\mathrm{O}$ (mol of $\mathrm{Cu})^{-1}$ ] at higher temperatures.

The change in surface oxygen coverage during an isothermal transient can be measured from the transient evolution in the rates of product formation. The feed contains equimolar amounts of $\mathrm{N}$ and $\mathrm{O}$; therefore, the net rate of oxygen adsorption, $r_{\mathrm{O} \text {,ads, }}$, equals the difference between the rates of appearance of $\mathrm{N}$ - and $\mathrm{O}$-atoms among reaction products (eq 1).

$$
r_{\mathrm{O}, \mathrm{ads}}=r_{\mathrm{N}, \mathrm{tot}}-r_{\mathrm{O}, \mathrm{tot}}=2 r_{\mathrm{N}_{2}}+r_{\mathrm{N}_{2} \mathrm{O}}-2 r_{\mathrm{O}_{2}}-r_{\mathrm{NO}_{2}}
$$

The integration of this net oxygen retention rate with time gives the fractional oxygen coverage on the surface, $\Theta_{\mathrm{O}}$. The starting point of this integration was estimated from an $\mathrm{O}_{2}$ TPD (in $\mathrm{He}$ ) for the catalyst $\mathrm{Cu}(0.36) .{ }^{27}$ During $\mathrm{O}_{2} \mathrm{TPD}$, up to $773 \mathrm{~K}, \sim 0.20$ 


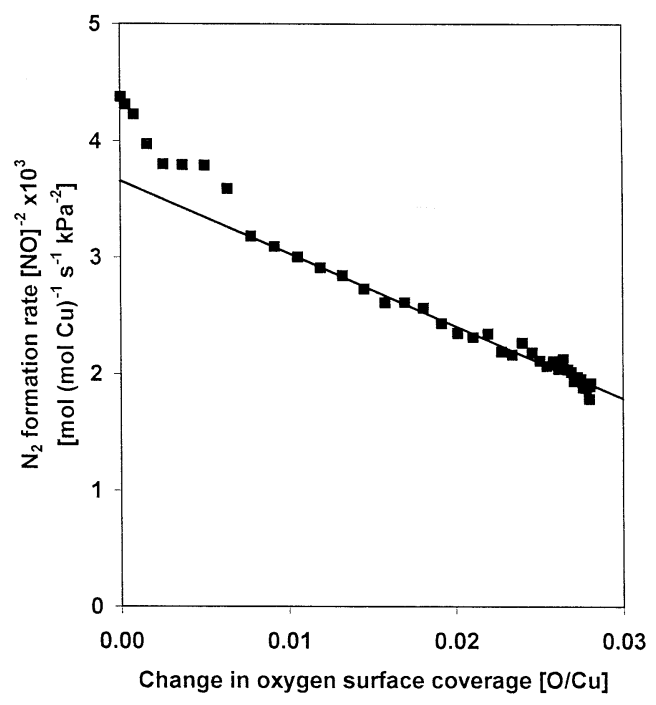

Figure 4. $\mathrm{N}_{2}$ formation rate during isothermal switch from pure $\mathrm{He}$ to $0.464 \% \mathrm{NO}$ at $773 \mathrm{~K}$ as a function of oxygen surface coverage [mol of $\left.\mathrm{O}(\mathrm{mol} \text { of } \mathrm{Cu})^{-1}\right]$. The $\mathrm{N}_{2}$ rate is divided by $[\mathrm{NO}]^{2}$ to account for the initial gradual increase in NO concentration caused by the system hydrodynamic delay $\left[\mathrm{Cu}(0.36), 0.1 \mathrm{~g}, 1.67 \mathrm{~cm}^{3} \mathrm{~s}^{-1}\right.$ total flow rate].

$\mathrm{O} / \mathrm{Cu}$ remains adsorbed on the catalyst and provides the initial oxygen content at the point of the He to NO switch.

During the initial part of the transient, the NO partial pressure gradually increased because of short (but measurable) hydrodynamic delays. This must be taken into account in the analysis of the transient kinetic response. The internal standard Ar was used to measure the inlet NO partial pressure during the isothermal transient, and this in turn was used to calculate a rate normalized to the NO partial pressure using a second-order NO dependence, obtained from steady-state kinetics. ${ }^{26}$

The effect of oxygen surface coverage, $\Theta_{\mathrm{O}}$, on $\mathrm{N}_{2}$ formation rates is shown in Figure 4 using the second-order NO concentration correction for the same experiment as in Figure 3. Except for the first few data points, $\mathrm{N}_{2}$ formation rates decreased linearly with increasing $\Theta_{\mathrm{O}}$, as expected from the reaction kinetics (eq 2), the details of which have been discussed elsewhere: ${ }^{26}$

$$
\frac{r_{\mathrm{N}_{2}}}{[\mathrm{NO}]^{2}}=k_{\mathrm{app}} \frac{[*]}{[\mathrm{L}]}=k_{\mathrm{app}} \frac{([\mathrm{L}]-[\mathrm{O} *])}{[\mathrm{L}]}=k_{\mathrm{app}}\left(1-\Theta_{\mathrm{O}}\right)
$$

At $773 \mathrm{~K}, \mathrm{O} *$ and * appear to be the most abundant surface species, and consistent with this, $\mathrm{NO}_{x}$-adsorbed species have not been detected by infrared spectroscopy at this temperature. ${ }^{12,18}$ Thus, an increase in $\Theta_{\mathrm{O}}$ corresponds to a proportional decrease in $\Theta^{*}$. The observed linear decrease in $\mathrm{N}_{2}$ formation rates is consistent with the requirement for reduced $\mathrm{Cu}$ centers (*) for NO chemisorption and decomposition steps, as well as the redox nature of NO decomposition catalytic cycles. Previously reported kinetic data ${ }^{26}$ showed that the steady-state reaction is second order in $\mathrm{NO}$, but the second-order correction overpredicts the rate during the initial hydrodynamic transient (Figure 4), whereas a correction that assumes a first-order NO dependence significantly underpredicts the rate. This indicates that $\mathrm{NO}$ adsorption steps are not fully quasi-equilibrated during the early stages of the transient, leading to an apparent NO reaction order slightly smaller than its steady-state value of two.

After steady-state NO decomposition rates were reached with $1.0 \% \mathrm{NO}$ reactants at $673 \mathrm{~K}$, a switch to pure He led to initial $\mathrm{O}_{2}$ formation rates significantly higher than at steady state (Figure 5). During the catalytic reaction, $\mathrm{O}_{2}$ formation rates

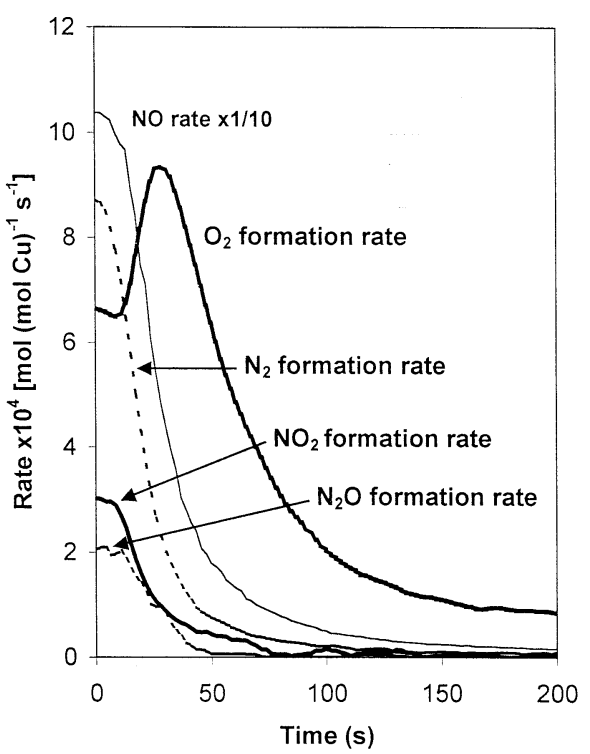

Figure 5. $\mathrm{N}_{2}, \mathrm{O}_{2}, \mathrm{~N}_{2} \mathrm{O}$, and $\mathrm{NO}_{2}$ formation rates and $\mathrm{NO}$ exit rate during an isothermal switch from $1 \% \mathrm{NO}$ to helium at $673 \mathrm{~K}[\mathrm{Cu}(0.58)$, $0.1 \mathrm{~g}, 1.67 \mathrm{~cm}^{3} \mathrm{~s}^{-1}$ total flow rate].

reflect the difference between the forward and the reverse rates of the elementary steps leading to the formation of $\mathrm{O}_{2}$. As a result, an increase in $\mathrm{O}_{2}$ formation rates after $\mathrm{NO}$ is removed from the gas phase can arise from either an increase in the forward rate of $\mathrm{O}_{2}$ evolution or from a decrease in the corresponding reverse rate (or from a combination of these two effects). The removal of NO from the gas phase leads to a gradual decrease in the concentration of all NO-derived adsorbed species, including chemisorbed oxygen. Therefore, the forward rate of formation of $\mathrm{O}_{2}$ from any such adsorbed species derived from $\mathrm{NO}$ cannot increase after $\mathrm{NO}$ is removed from the flowing stream. The higher than steady-state $\mathrm{O}_{2}$ formation rates observed after NO removal must therefore reflect a decrease in the rate of the microscopic reverse of the step that forms $\mathrm{O}_{2}$. The observed increase in the net $\mathrm{O}_{2}$ formation rate requires that a decrease in this reverse rate also occur more rapidly than any corresponding decrease in the forward rate of the $\mathrm{O}_{2}$ formation reaction. If $\mathrm{O}_{2}$ desorbed only via recombinative desorption of O* $\left(2 \mathrm{O}^{*} \leftrightarrow 2^{*}+\mathrm{O}_{2}\right)$, its microscopic reverse step-the dissociative chemisorption of $\mathrm{O}_{2}$-would actually increase upon the observed increase in the gas-phase $\mathrm{O}_{2}$ concentration. Thus, $\mathrm{O}_{2}$ removal cannot be occurring predominantly via recombinative desorption pathways during steady-state or transient NO decomposition. Instead, it appears that the reverse of the oxygen removal step involves $\mathrm{NO}$, the concentration of which decreases sharply and immediately after the switch. The surface species that form $\mathrm{O}_{2}$ also form $\mathrm{NO}$ concurrently, and the concentration of such species during steady-state NO decomposition must be large enough to account for the large excess of oxygen relative to nitrogen that desorbs in the products after removal of $\mathrm{NO}$ from the gas phase. $\mathrm{NO}_{3} *$ is the likely intermediate in $\mathrm{O}_{2}$ formation during $\mathrm{NO}$ decomposition; it has been detected as the most abundant infrared-active adsorbed species at these temperatures. ${ }^{12,18}$ These transient experiments provide kinetic evidence for its role as intermediate in $\mathrm{O}_{2}$ formation.

At $773 \mathrm{~K}$ and higher temperatures, the rate of $\mathrm{O}_{2}$ formation after removing $\mathrm{NO}$ from the gas phase was not above its value at steady state (Figure 6), indicating that the concentration of the adsorbed species responsible for $\mathrm{O}_{2}$ formation is significantly lower than at $673 \mathrm{~K}$. Infrared studies have shown that adsorbed $\mathrm{NO}_{3} *$ species disappear above $723 \mathrm{~K},{ }^{12,18}$ and $*$ and $\mathrm{O} *$ are 


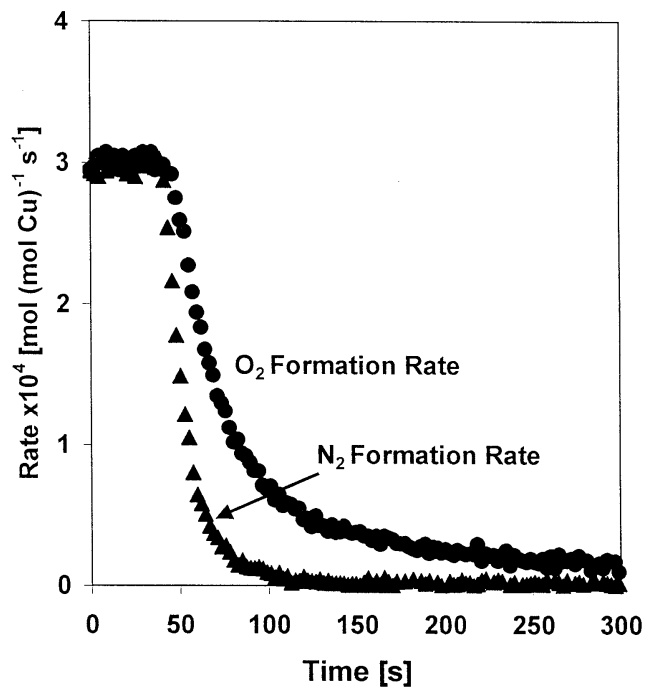

Figure 6. $\mathrm{N}_{2}$ and $\mathrm{O}_{2}$ formation rates during an isothermal switch from $0.464 \% \mathrm{NO}$ to pure $\mathrm{He}$ at $773 \mathrm{~K}$. This is a continuation from the experiment in Figure $3\left[\mathrm{Cu}(0.36), 0.1 \mathrm{~g}, 1.67 \mathrm{~cm}^{3} \mathrm{~s}^{-1}\right.$ total flow rate].

expected to become the most abundant reactive intermediates at these temperatures. The low $\mathrm{NO}_{3}{ }^{*}$ surface coverages detected at high temperatures are consistent with an exothermic adsorption process, such as $\mathrm{NO}_{2}$ adsorption on oxidized dimers $\left(\mathrm{O}^{*}\right)$, for which the equilibrium constant decreases with increasing temperature. The absence of detectable $\mathrm{NO}_{3} *$ at temperatures above $700 \mathrm{~K}$ reflects the stronger temperature dependence for $\mathrm{NO}_{3} *$ decomposition relative to its formation, as expected for exothermic reactions. This evidence does not preclude an intermediate role for $\mathrm{NO}_{3} *$ in $\mathrm{O}_{2}$ formation during steady-state NO decomposition at these higher temperatures, but only its presence as a detectable reactive intermediate. Decomposition reactions of $\mathrm{NO}_{3} *$ and other adsorbed $\mathrm{NO}_{\mathrm{x}}$ species are discussed in more detail in the following two sections.

Desorption and Reactions of Preadsorbed NO as a Function of Temperature. Reactions of adsorbed NO during temperature ramping in He flow led to the evolution of unreacted $\mathrm{NO}$ and of $\mathrm{O}_{2}, \mathrm{~N}_{2} \mathrm{O}$, and small amounts of $\mathrm{N}_{2}$ for all samples (Figures 7 and 8). These results are in qualitative agreement with previous studies on $\mathrm{Cu}-$ ZSM5 catalysts. ${ }^{10,12,20-23} \mathrm{NO}$ evolution occurs over a broad temperature range $(300-750 \mathrm{~K})$, as three broad peaks centered at about 380,490 , and $660 \mathrm{~K}$ on all catalysts, whereas $\mathrm{O}_{2}$ desorbs as a single peak at higher temperatures $(\sim 660 \mathrm{~K})$. $\mathrm{N}_{2} \mathrm{O}$ forms at room temperature during $\mathrm{NO}$ adsorption on He-treated samples and desorbs also in two other peaks at 380 and $620 \mathrm{~K}(\mathrm{Cu}(0.60)$, Figure 7). On samples treated in $50 \% \mathrm{O}_{2} / \mathrm{He}$ before $\mathrm{NO}$ chemisorption, only the two $\mathrm{N}_{2} \mathrm{O}$ peaks at elevated temperatures appear in substantial amounts, and the total amount of desorbed $\mathrm{N}_{2} \mathrm{O}\left(0.08 \mathrm{~N}_{2} \mathrm{O} / \mathrm{Cu}\right.$, Figure $8 \mathrm{~b}$ ) is smaller than for samples treated in He before contact with $\mathrm{NO}$ at ambient temperature $\left(0.20 \mathrm{~N}_{2} \mathrm{O} / \mathrm{Cu}\right.$, Figure 8a). The larger amount of $\mathrm{N}_{2} \mathrm{O}$ formed on He-treated samples, which contain a larger number of reduced $\mathrm{Cu}$ dimers $(*),{ }^{27}$ implicates such sites in the formation and reactions of adsorbed $\mathrm{NO}$ species, with the subsequent formation of $\mathrm{O}^{*}$ after $\mathrm{N}_{2} \mathrm{O}$ desorption.

As expected from the larger fraction of $\mathrm{Cu}$ that appears as $\mathrm{Cu}$ dimers on $\mathrm{Cu}(0.60)$, the amount of $\mathrm{N}_{2} \mathrm{O}$ formed on this catalyst $\left(0.22 \mathrm{~N}_{2} \mathrm{O} / \mathrm{Cu}\right)$ is larger than that on $\mathrm{Cu}(0.36)(0.20$ $\mathrm{N}_{2} \mathrm{O} / \mathrm{Cu}$ ). The similar desorption profiles for samples with a wide range of $\mathrm{Cu} / \mathrm{Al}$ ratio suggest that similar $\mathrm{Cu}$ species are prevalent on these samples, albeit with different relative abundances. As a result, similar NO decomposition pathways,

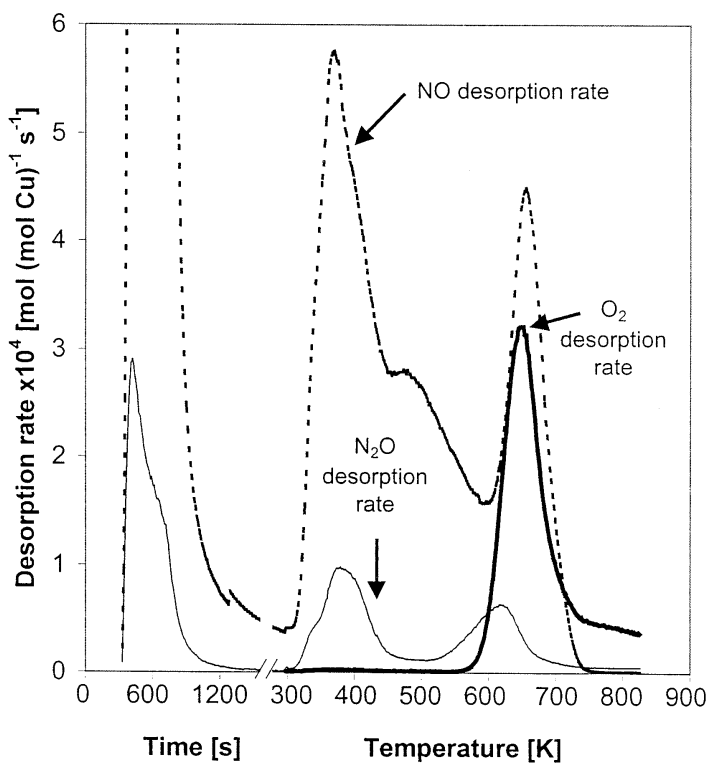

Figure 7. Evolution of products from preadsorbed NO during temperature programming in $\mathrm{He}$ carrier gas on $\mathrm{Cu}(0.60)$ treated in $\mathrm{He}$ at $773 \mathrm{~K}$ for $2 \mathrm{~h}$ before $\mathrm{NO}$ adsorption. $\mathrm{N}_{2} \mathrm{O}$ formation is shown during $\mathrm{NO}$ adsorption at $298 \mathrm{~K}$. Zero in the time scale represents the time at which NO flow started. The temperature was ramped from 298 to 823 $\mathrm{K}$ at $0.167 \mathrm{~K} \mathrm{~s}^{-1}$ after $\mathrm{NO}$ was removed from the gas phase $[0.3 \mathrm{~g}$, $1.67 \mathrm{~cm}^{3} \mathrm{~s}^{-1}$ total flow rate].

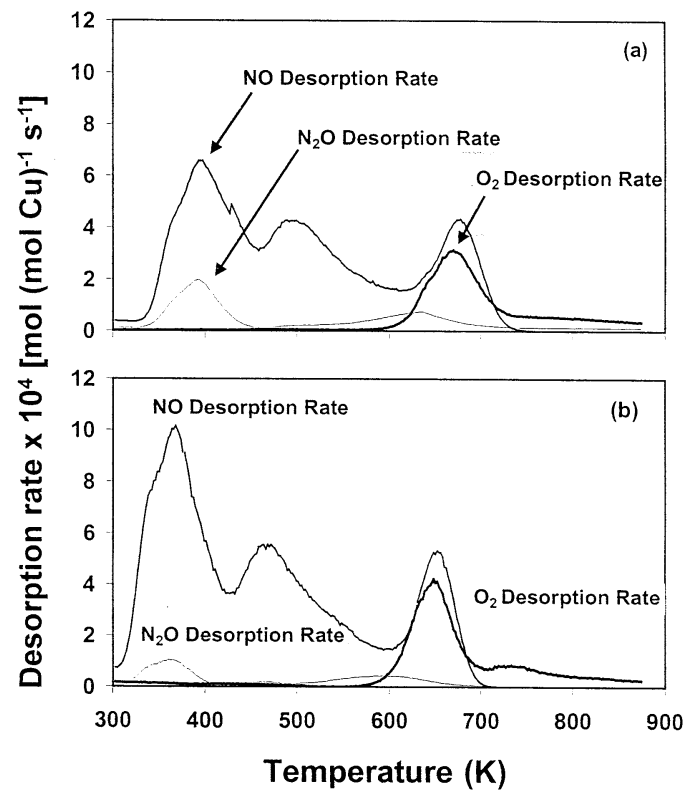

Figure 8. (a) Evolution of products from preadsorbed NO during temperature programming in $\mathrm{He}$ carrier gas on $\mathrm{Cu}(0.36)$ treated in $\mathrm{He}$ at $773 \mathrm{~K}$ for $2 \mathrm{~h}$ before NO adsorption. The temperature was ramped from 298 to $823 \mathrm{~K}$ at $0.167 \mathrm{~K} \mathrm{~s}^{-1}\left[0.3 \mathrm{~g}, 1.67 \mathrm{~cm}^{3} \mathrm{~s}^{-1}\right.$ total flow rate]. (b) Evolution of products from preadsorbed NO during temperature programming in $\mathrm{He}$ carrier gas on $\mathrm{Cu}(0.36)$ treated in $50 \% \mathrm{O}_{2} / \mathrm{He}$ at $773 \mathrm{~K}$ for $2 \mathrm{~h}$ before NO adsorption. The temperature was ramped from 298 to $823 \mathrm{~K}$ at $0.167 \mathrm{~K} \mathrm{~s}^{-1}\left[0.3 \mathrm{~g}, 1.67 \mathrm{~cm}^{3} \mathrm{~s}^{-1}\right.$ total flow rate].

but a varying number of active sites, are expected on these samples. ${ }^{27}$

At $298 \mathrm{~K}, \mathrm{NO}$ adsorption leads to infrared bands for $\mathrm{Cu}^{+}$(NO) and $\mathrm{Cu}^{+}(\mathrm{NO})_{2}$ on $\mathrm{Cu}-\mathrm{ZSM} 5$ samples pretreated in $\mathrm{He}$ at $823 \mathrm{~K} \cdot{ }^{5,16}$ These bands become less intense with increasing time in contact with $\mathrm{NO}$, during which they are gradually replaced with bands assigned to $\mathrm{Cu}^{2+} \mathrm{O}^{-}(\mathrm{NO})$. This oxidation of $\mathrm{Cu}^{+}$to $\mathrm{Cu}^{2+}$ is consistent with the observed evolution of $\mathrm{N}_{2} \mathrm{O}$ from adsorbed $\mathrm{NO}$ near ambient temperature (Figure 7). 
The evolution of $\mathrm{N}_{2} \mathrm{O}$ at ambient temperatures indicates that the activation energy for $\mathrm{N}_{2} \mathrm{O}$ formation is very low. Reduced $\mathrm{Cu}$ dimers (*) provide two vicinal $\mathrm{NO}$ adsorption sites, and such structures allow the formation of $\mathrm{N}-\mathrm{N}$ bonds with low activation barriers. As discussed elsewhere, ${ }^{26}$ this low activation energy, together with the significant adsorption enthalpy for NO on reduced $\mathrm{Cu}$ atoms within such dimers, leads to the negative apparent activation energy observed on $\mathrm{Cu}-\mathrm{ZSM} 5$ catalysts at high temperatures.

The $\mathrm{N}_{2} \mathrm{O}$ desorption peak at $380 \mathrm{~K}$ (Figures 7 and 8) coincides with the first $\mathrm{NO}$ desorption peak, suggesting that $\mathrm{N}_{2} \mathrm{O}$ desorbs concurrently with some of the adsorbed NO. $\mathrm{Cu}^{+}(\mathrm{NO})$ infrared bands become weaker at $\sim 373 \mathrm{~K}$ during steady-state NO decomposition. ${ }^{16}$ Thus, it seems that isolated and unreactive $\mathrm{Cu}^{+}(\mathrm{NO})$ species (NO*), adsorbed on one of the two $\mathrm{Cu}^{+}$atoms within a reduced dimer, become reactive as adsorbed NO becomes mobile during desorption and reequilibrates to form the two vicinal $\mathrm{Cu}^{+}(\mathrm{NO})$ species required for $\mathrm{N}-\mathrm{N}$ bond formation. The readsorption of $\mathrm{NO}$ as it desorbs and moves along the catalyst bed leads to the formation of some dimers with the required two $\mathrm{NO}$ molecules. As a result, $\mathrm{NO}$ and $\mathrm{N}_{2} \mathrm{O}$ appear simultaneously in the gas phase during these experiments (Figures 7 and 8). The steps involved are shown schematically in eqs $3-5$, as previously suggested. ${ }^{7}$
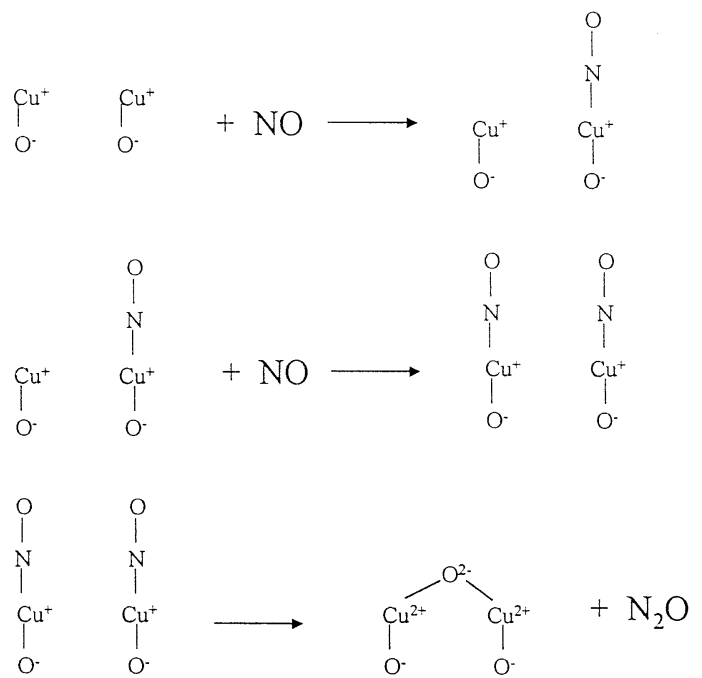

NO desorbs at $490 \mathrm{~K}$ without the concurrent evolution of any other species, indicating that $\mathrm{NO}$ does not react to form $\mathrm{N}-\mathrm{N}$ bonds or $\mathrm{NO}_{2}$ molecules via reactions with reduced or oxidized $\mathrm{Cu}$ dimers at these temperatures. The species responsible for this NO desorption peak appear to be spectators, distinct from those adsorbed on reduced $\mathrm{Cu}$ dimers.

The third $\mathrm{N}_{2} \mathrm{O}$ peak at $\sim 620 \mathrm{~K}$ is assigned to the readsorption of some of the NO desorbed at $\sim 490 \mathrm{~K}$ on $\mathrm{Cu}$ dimers that have been reduced by the process responsible for the incipient desorption of $\mathrm{O}_{2}$ at $\sim 650 \mathrm{~K}$. It is likely, as discussed below, that these sites are formed by reaction of NO with $\mathrm{O}^{*}$ to form $\mathrm{NO}_{2}$ (eq 6), which then readsorbs on other oxidized dimers to form $\mathrm{NO}_{3} *$ (eq 7). At these temperatures, $\mathrm{NO}_{3} *$ species are stable and most of the desorbed $\mathrm{NO}_{2}$ molecules tend to readsorb on oxidized $\mathrm{Cu}$ dimers.

$\mathrm{O}_{2}$ desorbs in a peak at $660 \mathrm{~K}$, simultaneously with the last NO desorption peak. This simultaneous evolution of NO and $\mathrm{O}_{2}$ indicates that they form via decomposition of a common intermediate. $\mathrm{NO} / \mathrm{O}_{2}$ molar ratios for these peaks are between 1 and 2, with the higher ratios observed on samples pretreated

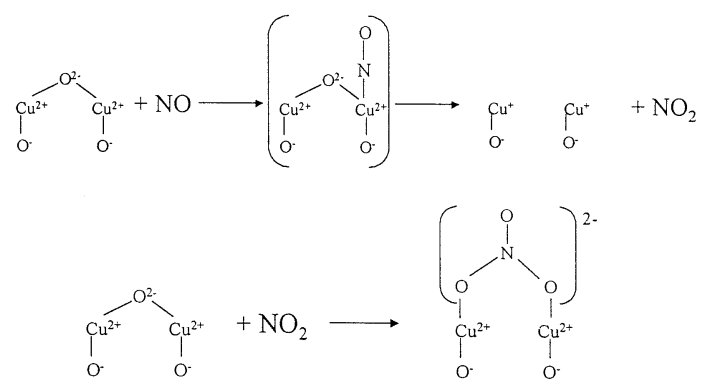

in $\mathrm{He}$ instead of $50 \% \mathrm{O}_{2} / \mathrm{He}$. These $\mathrm{NO} / \mathrm{O}_{2}$ ratios are consistent with adsorbed $\mathrm{NO}_{3}$, and these ratios reflect a mixture of $\mathrm{Cu}$ sites in their reduced $(*)$ and oxidized $\left(\mathrm{O}^{*}\right)$ states as end products, as shown in eqs 8 and 9 , which would lead to ratios

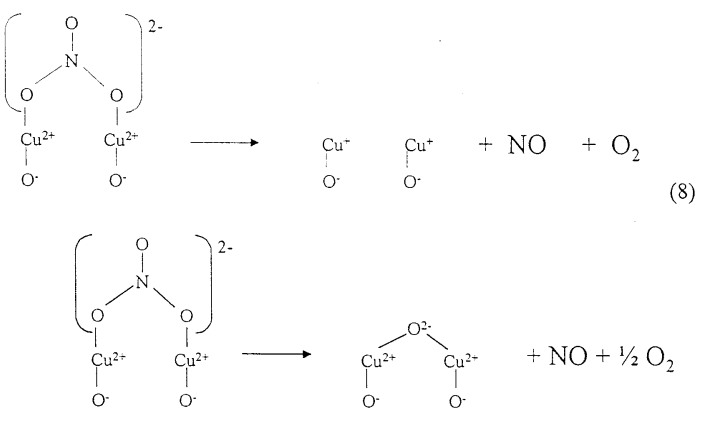

(9)

of 1 and 2, respectively. Equation 9 reflects the net decomposition of $\mathrm{NO}_{3}{ }^{*}$ to form $\mathrm{O}^{*}$ and it is not necessarily an elementary step. $\mathrm{NO}_{2}$ is the first desorption product in this sequence, but low concentrations of $\mathrm{NO}$ and $\mathrm{O}_{2}$ and unfavorable thermodynamics lead to the catalytic decomposition of $\mathrm{NO}_{2}$ into $\mathrm{NO}$ and $\mathrm{O}_{2}$ via the reverse of step 6 and steps 7 and 8 .

Above $700 \mathrm{~K}, \mathrm{O}_{2}$ desorbs in small amounts via the recombination of remaining $\mathrm{O}^{*}$ sites. The $\mathrm{NO}_{3}$ pathway for $\mathrm{O}_{2}$ formation becomes unavailable for these $\mathrm{O} *$ sites because NO is no longer present in the contacting gas phase at these high temperatures. The infrared bands associated with $\mathrm{NO}_{3}$ * disappear around $673 \mathrm{~K}$, without the detection of any bands for adsorbed NO. ${ }^{12,18}$ This is consistent with the mechanism for the concurrent evolution of $\mathrm{NO}$ and $\mathrm{O}_{2}$ at $660 \mathrm{~K}$ on $\mathrm{Cu}-\mathrm{ZSM} 5$ proposed this study. These mechanistic conclusions have been confirmed by the results obtained from reactions of adsorbed $\mathrm{NO}$ in the presence of $\mathrm{NO}$ in the gas phase, as discussed in the next section.

Desorption and Decomposition of Adsorbed NO Using NO-Containing Carrier Gas. Here, we examine desorption and reactions of adsorbed $\mathrm{NO}$ as the sample temperature is increased in the presence of gas-phase NO. The results are shown in Figure 9 for $\mathrm{Cu}(0.58)$ pretreated in $50 \% \mathrm{O}_{2} / \mathrm{He}$. At low temperatures, $\mathrm{N}_{2} \mathrm{O}$ is formed, as in the case of reactions of preadsorbed $\mathrm{NO}$ with $\mathrm{He}$ as a carrier gas. This sample shows detectable amounts of $\mathrm{N}_{2} \mathrm{O}$, even though reduced sites are not expected to remain after treatment at $773 \mathrm{~K}$ and cooling to ambient temperature in an $\mathrm{O}_{2}$-containing stream. As shown in eqs $3-5$ and previously proposed, ${ }^{6,7}$ formation of $\mathrm{N}_{2} \mathrm{O}$ requires reduced $\mathrm{Cu}$ dimers.

One pathway for $\mathrm{N}_{2} \mathrm{O}$ formation on samples containing only oxidized dimers $\left(\mathrm{O}^{*}\right)$ involves the reduction of dimers by NO to form $\mathrm{NO}_{2}$ molecules (eq 6), which then readsorb on other oxidized dimers to form stable $\mathrm{NO}_{3} *$ species. The formation and desorption of $\mathrm{NO}_{2}$ in the first step forms a reduced $\mathrm{Cu}$ dimer, which becomes available for adsorption and for sto- 


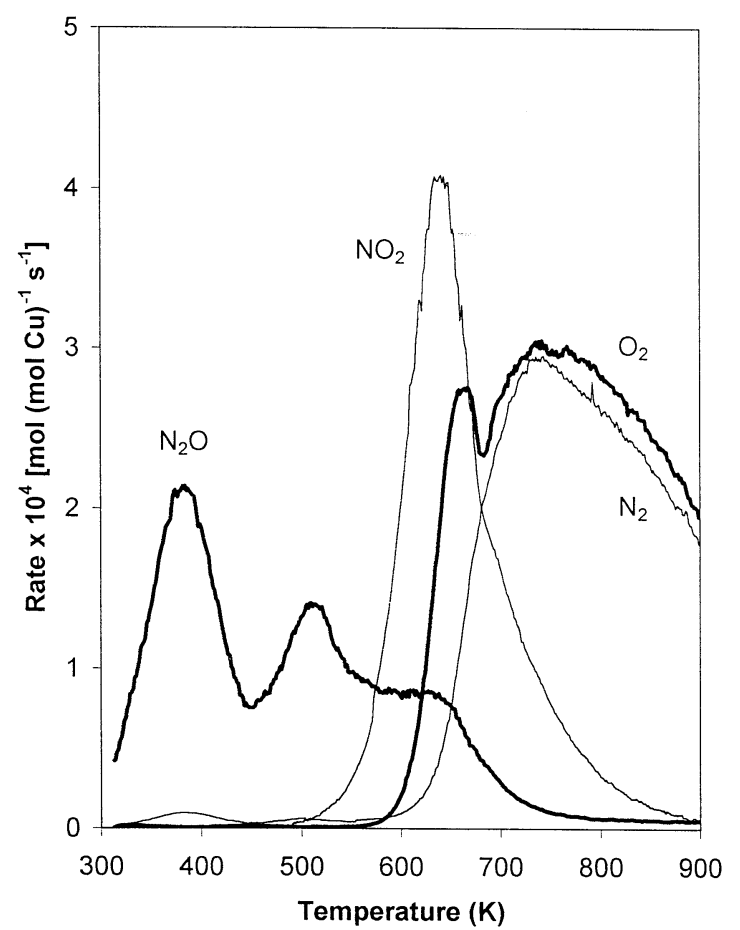

Figure 9. Rates of product evolution and $\mathrm{NO}$ molar rates in effluent during reactions of $0.464 \% \mathrm{NO} / \mathrm{He}$ on $\mathrm{Cu}(0.58)$ initially treated in $50 \%$ $\mathrm{O}_{2} / \mathrm{He}$ at $773 \mathrm{~K}$ for $2 \mathrm{~h}$. The temperature was ramped from 298 to 900 $\mathrm{K}$ at $0.167 \mathrm{~K} \mathrm{~s}^{-1}\left[0.3 \mathrm{~g}, 1.67 \mathrm{~cm}^{3} \mathrm{~s}^{-1}\right.$ total flow rate].

ichiometric decomposition of $\mathrm{NO}$ to $\mathrm{N}_{2} \mathrm{O}$ and $\mathrm{O} *$ near ambient temperatures (eq 5). The formation of $\mathrm{NO}_{3} *$ leads to the accumulation of a larger amount of oxygen than in fully oxidized fresh samples ( 1 vs $0.5 \mathrm{O} / \mathrm{Cu}_{\text {dimer }}$ in addition to adsorbed $\mathrm{NO}$ ). In this manner, the oxidation of $\mathrm{NO}$ to $\mathrm{NO}_{2}$ allows the concurrent reduction of two $\mathrm{NO}$ molecules to one $\mathrm{N}_{2} \mathrm{O}$ molecule with the overall stoichiometry of eq 10 .

$$
\mathrm{O} *+3 \mathrm{NO} \rightarrow \mathrm{NO}_{3}^{*}+\mathrm{N}_{2} \mathrm{O}
$$

Another possibility for the accumulation of adsorbed oxygen species during formation of $\mathrm{N}_{2} \mathrm{O}$ on oxidized samples is the adsorption of $\mathrm{NO}_{2}$, as previously suggested from infrared data. ${ }^{6}$ NO could reduce $\left\{\mathrm{Cu}^{2+}-\mathrm{O}^{2-}-\mathrm{Cu}^{2+}\right\}^{2+}$ dimers, leading to $\mathrm{Cu}^{+}$(NO) and to $\mathrm{NO}_{2}$ adsorbed as a $\left(\mathrm{Cu}-\mathrm{NO}_{2}\right)^{+}$complex near room temperature. However, these $\mathrm{NO}_{2}$ species must desorb for two $\mathrm{Cu}^{+}(\mathrm{NO})$ species to coexist within a dimer and then react to form the observed $\mathrm{N}_{2} \mathrm{O}$ products. Therefore, although via a different sequence, this mechanism involves the same elementary steps for $\mathrm{N}_{2} \mathrm{O}$ formation as those described in the previous paragraph. The $\mathrm{NO}_{2}$ desorbed is not detected in the effluent because it readsorbs at these low temperatures to form $\mathrm{NO}_{3}$ * on the predominant $\mathrm{Cu}$ structures (oxidized $\mathrm{Cu}$ dimers).

$\mathrm{N}_{2} \mathrm{O}$ formation rates ultimately decrease as the temperature increases above $373 \mathrm{~K}$ (Figure 9), even though NO reactants remain in the gas phase. No oxygen-containing products, except $\mathrm{N}_{2} \mathrm{O}$, are detected below $500 \mathrm{~K}$; this indicates that oxygen must accumulate on the surface in the $300-500 \mathrm{~K}$ range, leading to a gradual increase in the oxygen content of the most abundant adsorbed species. As discussed above, these species are likely to be adsorbed $\mathrm{NO}_{3} *$ structures, which decompose only at higher temperatures. $\mathrm{N}_{2} \mathrm{O}$ formation decreases with increasing temperature because $\mathrm{NO}_{3}$ * species occupy most of the $\mathrm{Cu}$ dimer sites. These pathways provide a stoichiometric reaction for the formation of $\mathrm{N}_{2} \mathrm{O}$ (eq 10). The kinetic coupling of this reaction with $\mathrm{NO}_{3} *$ decomposition completes the catalytic cycle for $\mathrm{NO}$ decomposition by providing a pathway for net oxygen removal, but only at higher temperatures, which are required for $\mathrm{NO}_{3} *$ decomposition.

As the temperature increases above $500 \mathrm{~K}$, large amounts of $\mathrm{NO}_{2}$ desorb from the catalyst $\left(0.27 \mathrm{NO}_{2} / \mathrm{Cu}\right)$ as $\mathrm{NO}_{3} *$ becomes unstable. At these temperatures quasi-equilibrium is achieved among $\mathrm{NO}_{2}, \mathrm{NO}$, and $\mathrm{O}_{2}$ molecules in the gas phase. ${ }^{26,29,30}$ Thermodynamics favor $\mathrm{NO}_{2}$ at low temperatures; as a result, $\mathrm{NO}_{2}$ is the predominant product of $\mathrm{NO}_{3} *$ decomposition at $\sim 623$ $\mathrm{K}$, whereas $\mathrm{NO}$ and $\mathrm{O}_{2}$ are thermodynamically favored at higher temperatures (Figure 9). The amount of $\mathrm{NO}_{2}$ formed in this experiment is much larger than that formed when $\mathrm{He}$ is used as the carrier gas (see previous section), because $\mathrm{NO}$ and $\mathrm{O}_{2}$ concentrations are much higher when the carrier gas contains $\mathrm{NO}$ and this leads to higher equilibrium $\mathrm{NO}_{2}$ concentrations.

$\mathrm{O}_{2}$ evolution starts at $\sim 573 \mathrm{~K}$ and it reaches maximum rates at $670 \mathrm{~K}$ (Figure 9). These $\mathrm{O}_{2}$ formation pathways are identical to those involved in the decomposition of preadsorbed NO in a He carrier. $\mathrm{O}_{2}$ forms in this case, however, via both stoichiometric decomposition of adsorbed $\mathrm{NO}_{3} *$ and via catalytic decomposition of some of the NO present in the gas phase, which also involves a $\mathrm{NO}_{3} *$ decomposition step. At temperatures above those required for $\mathrm{NO}_{3} *$ decomposition $(\sim 685 \mathrm{~K}), \mathrm{N}_{2}$ and $\mathrm{O}_{2}$ evolve in nearly equimolar amounts via steady-state catalytic reactions of gas-phase NO molecules. A residual slight excess of $\mathrm{O}_{2}$ in the effluent stream, however, indicates that net oxygen removal from these samples continues up to $923 \mathrm{~K}$. This leads to an increasing concentration of $\left\{\mathrm{Cu}^{+}-\square-\mathrm{Cu}^{+}\right\}^{2+}$ species with increasing temperature, as suggested also by steadystate NO decomposition rate measurements. ${ }^{26}$

Assessment of $\mathrm{O}_{2}$ Formation Mechanism during Catalytic and Stoichiometric Reactions of NO. The isothermal and nonisothermal transient data described above suggest that $\mathrm{O}_{2}$ formation pathways involve $\mathrm{NO}$ molecules as oxygen carriers. These carriers allow kinetic communication among oxygen atoms present at distant $\mathrm{Cu}$ dimers, via the quasi-equilibrated formation and decomposition of $\mathrm{NO}_{2}$. Indeed, the equilibrium $\mathrm{NO}_{2}$ concentrations prevalent during steady-state catalytic NO decomposition at $673-873 \mathrm{~K}$ ensure that such pathways are sufficiently fast to equilibrate gas-phase and surface oxygen pools and to account for all of the $\mathrm{O}_{2}$ desorbed during steadystate NO decomposition. ${ }^{26}$

These conclusions were confirmed by measuring the net rate of oxygen removal from $\mathrm{Cu}$-ZSM5 samples during heating in the presence and absence of NO in the carrier gas (Figure 10). In the absence of $\mathrm{NO}\left(\mathrm{O}_{2}\right.$ TPD $), \mathrm{O}_{2}$ desorbs only via recombination of $\mathrm{O}^{*}$ species associated with $\mathrm{Cu}$ dimers or, if present, with $\mathrm{CuO}$ clusters. This process requires two oxygen atoms to be sufficiently near to form $\mathrm{O}=\mathrm{O}$ bonds, either because of their permanent proximate location as part of vicinal oxidized dimers or after surface or gas-phase diffusion of O-atoms at much higher temperatures. When NO is present in the carrier gas, both NO-mediated transport in the gas phase and $\mathrm{O}^{*}$ recombination desorption pathways become possible; in this case, all $\mathrm{Cu}$ dimers become active in redox processes irrespective of whether they are located within or beyond atomic $\mathrm{O}-\mathrm{O}$ distances from each other. When NO is present in the carrier gas, the net oxygen removal rate was estimated using eq 2 . Figure 11 shows the cumulative change in oxygen surface coverage, estimated by integration of the data in Figure 10 with the assumption that samples initially contain one $\mathrm{O}$ per $\mathrm{Cu}$ dimer. This assumption was confirmed and the number of $\mathrm{Cu}$ dimers was estimated from $\mathrm{H}_{2}$ and $\mathrm{CO}$ reduction experiments. ${ }^{27}$

The recombinative $\mathrm{O}_{2}$ desorption profile observed using $\mathrm{He}$ as the carrier gas (Figure 10) shows two features, as reported 


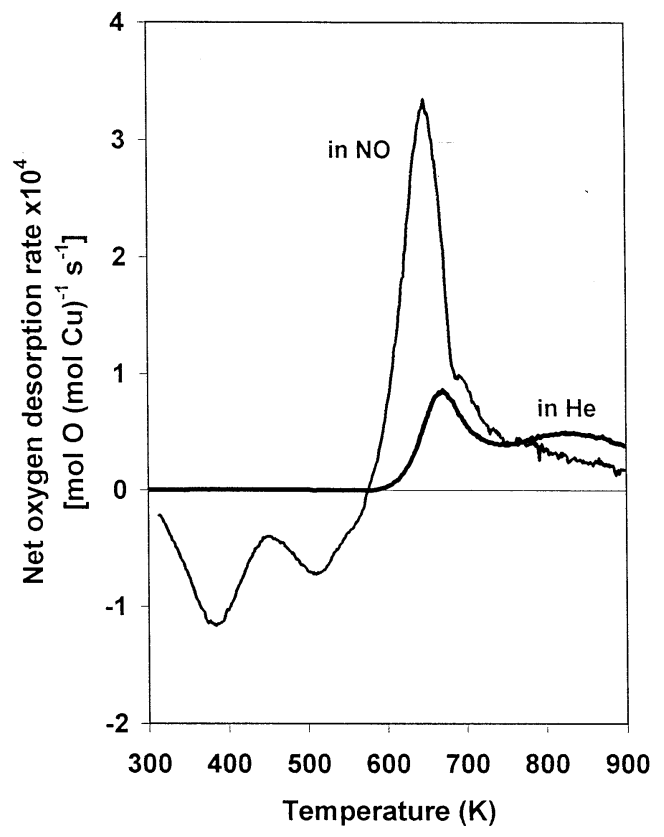

Figure 10. Net $\mathrm{O}$ evolution rates during reactions of $0.464 \% \mathrm{NO} / \mathrm{He}$ (labeled "in NO") and during desorption in He (labeled "in He") on $\mathrm{Cu}(0.58)$ treated in $50 \% \mathrm{O}_{2} / \mathrm{He}$ at $773 \mathrm{~K}$ for $2 \mathrm{~h}$ before desorption in $\mathrm{He}$ or NO reactions. The NO experiment is the same as the one presented in Figure 9.

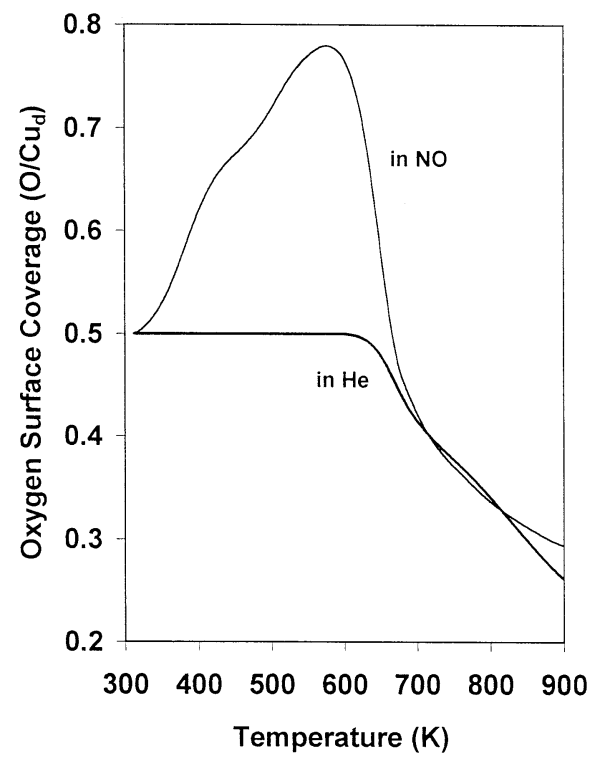

Figure 11. Oxygen surface coverage $\left(\mathrm{O} / \mathrm{Cu}_{\text {dimer }}\right)$ relative to starting material for the same experiments as in Figure 10. The integration is started at $0.5 \mathrm{O} / \mathrm{Cu}_{\mathrm{dimer}}$.

also in a previous study. ${ }^{24}$ A low-temperature peak at $\sim 650 \mathrm{~K}$ appears to reflect vicinal oxygen-containing species, which would require minimal oxygen mobility for recombination events. This peak increases with increasing $\mathrm{Cu} / \mathrm{Al}$ ratio, as expected from the decrease in the average distance among $\mathrm{Cu}$ dimers as the $\mathrm{Cu}$ content increases. ${ }^{27} \mathrm{~A}$ broader peak at $\sim 800$ $\mathrm{K}$ is likely to require mobility of $\mathrm{O}^{*}, \mathrm{Cu}$ dimers, or even framework cations. Additional details about the $\mathrm{O}_{2}$ desorption kinetics and the structure of $\mathrm{Cu}$ species in these materials are reported elsewhere. ${ }^{27}$

When NO molecules are present in the carrier gas, the oxygen content in $\mathrm{Cu}-\mathrm{ZSM} 5$ increases as the sample temperature increases from 298 to $573 \mathrm{~K}$, because of the formation of $\mathrm{NO}_{3} *$, as mentioned in the previous section (Figure 11). Above $\sim 573$ $\mathrm{K}, \mathrm{NO}_{3} *$ becomes unstable and decomposes according to eqs 8

\begin{tabular}{|c|c|c|c|c|c|c|c|}
\hline \multicolumn{8}{|c|}{ NO activation and $\mathrm{N}_{2} \mathrm{O}$ and $\mathrm{N}_{2}$ formation } \\
\hline 1. & * & + & NO & 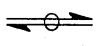 & \multicolumn{2}{|l|}{ NO* } & (quasi-equilibrated) \\
\hline 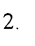 & $\mathrm{NO}^{*}$ & + & NO & 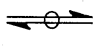 & \multicolumn{2}{|c|}{$(\mathrm{NO})_{2}{ }^{*}$} & (quasi-equilibrated) \\
\hline 3. & \multicolumn{3}{|c|}{$(\mathrm{NO})_{2}{ }^{*}$} & $\longrightarrow$ & $\mathrm{O}^{*}$ & $+\mathrm{N}_{2} \mathrm{O}$ & \\
\hline 4. & * & + & $\mathrm{N}_{2} \mathrm{O}$ & $\rightleftharpoons$ & \multicolumn{2}{|l|}{$\mathrm{N}_{2} \mathrm{O}^{*}$} & (quasi-equilibrated) \\
\hline 5. & $\mathrm{~N}_{2} \mathrm{O}^{*}$ & & & $\longrightarrow$ & $\mathrm{O}^{*}$ & $+\mathrm{N}_{2}$ & \\
\hline \multicolumn{8}{|c|}{$\underline{\mathrm{O}}_{2}$ formation } \\
\hline 6. & $\mathrm{O}^{*}$ & + & NO & $\Longrightarrow$ & $\mathrm{NO}_{2}{ }^{*}$ & & (quasi-equilibrated) \\
\hline 7. & $\mathrm{NO}_{2}{ }^{*}$ & & & $\Longrightarrow$ & * & $+\mathrm{NO}_{2}$ & (quasi-equilibrated) \\
\hline 8. & $\mathrm{O}^{*}$ & + & $\mathrm{NO}_{2}$ & $\rightleftharpoons$ & $\mathrm{NO}_{3} *$ & & (quasi-equilibrated) \\
\hline 9. & $\mathrm{NO}_{3}{ }^{*}$ & & & $\rightleftharpoons$ & $\mathrm{O}_{2}^{*}$ & $+\mathrm{NO}$ & (quasi-equilibrated) \\
\hline 10. & $\mathrm{O}_{2} *$ & & & $\Longrightarrow$ & * & $+\mathrm{O}_{2}$ & (quasi-equilibrated) \\
\hline
\end{tabular}

Figure 12. Proposed mechanism for $\mathrm{NO}$ decomposition on $\mathrm{Cu}-\mathrm{ZSM} 5$.

and 9. This results in the net removal of oxygen atoms from the samples, the rate of which reaches a maximum value at $\sim 623$ $\mathrm{K}$. The catalyst oxygen content in the NO-containing carrier gas then rapidly approaches that measured with pure He as the carrier gas and ultimately becomes slightly lower than the latter at $\sim 700 \mathrm{~K}$. Thus, even though $\mathrm{O} *$ is continuously formed during $\mathrm{NO}$ decomposition and the concentration of $\mathrm{O}_{2}$ in the gas phase is much higher than with the pure He carrier gas, the oxygen content in the catalyst is lower when NO is present in the contacting gas phase. Clearly, the pathways available for oxygen removal are more effective when $\mathrm{NO}$ is present, as expected if $\mathrm{NO}$ were involved in facilitating $\mathrm{O}_{2}$ formation via $\mathrm{NO}_{2}$ formation-decomposition equilibrated pathways.

Above $\sim 700 \mathrm{~K}, \mathrm{NO}_{3} *$ coverages are negligible, and $\mathrm{O}^{*}$ and * become the most abundant surface species in both the presence and absence of NO. When NO is present, $\mathrm{O}_{2}$ and $\mathrm{O}^{*}$ are in quasi-equilibrium (via the $\mathrm{NO}_{2}-\mathrm{NO}$ redox reaction) and oxygen removal rates above $700 \mathrm{~K}$ are controlled by the temperaturedependent equilibrium constant for $\mathrm{O}_{2}$ adsorption, which sets its concentration in the flowing gas. ${ }^{26}$ With pure $\mathrm{He}$ as the carrier, $\mathrm{O}^{*}$ is not formed continuously and $\mathrm{O}_{2}$ formation rates are controlled by the kinetics of recombinative desorption. Thus, at high temperatures, $\mathrm{Cu}$ species from which $\mathrm{O}^{*}$ has desorbed remain reduced with $\mathrm{He}$ as the carrier gas, while such reduced species are continuously reoxidized as part of redox cycles responsible for $\mathrm{NO}$ decomposition turnovers when $\mathrm{NO}$ is present in the gas phase. This explains why the oxygen content becomes comparatively lower in the absence of NO above 800 $\mathrm{K}$ (Figure 11).

We have shown that $\mathrm{NO}$-mediated pathways for $\mathrm{O}_{2}$ formation are more rapid than $\mathrm{O}^{*}$ recombination to form $\mathrm{O}_{2}$. These pathways also allow all $\mathrm{Cu}$ dimers to become potential active sites for NO decomposition, because such pathways do not require vicinal $\mathrm{Cu}$ dimers to complete catalytic turnovers via recombinative $\mathrm{O}_{2}$ formation.

Our results are relevant also to the mechanism for $\mathrm{N}_{2} \mathrm{O}$ decomposition reactions on $\mathrm{Cu}-\mathrm{ZSM} 5^{31-36}$ and $\mathrm{Fe}-\mathrm{ZSM} 5 .{ }^{37-39}$ $\mathrm{N}_{2} \mathrm{O}$ is an intermediate in $\mathrm{NO}$ decomposition, and its ultimate decomposition to $\mathrm{N}_{2}$ and $\mathrm{O}_{2}$ is required in order to complete $\mathrm{NO}$ decomposition turnovers. Thus, $\mathrm{NO}$ and $\mathrm{N}_{2} \mathrm{O}$ decomposition reactions are mechanistically entangled. Both reactions require the stoichiometric formation of $\mathrm{O}_{2}$, the mechanism of which is common to both reactions. Oscillatory $\mathrm{N}_{2} \mathrm{O}$ decomposition rates $^{31}$ have been attributed to the gradual accumulation and rapid decomposition of adsorbed nitrate species, ${ }^{32,33}$ a conclusion recently confirmed by infrared studies. ${ }^{36} \mathrm{On} \mathrm{Cu}-\mathrm{ZSM}^{32}$ and $\mathrm{Fe}-\mathrm{ZSM} 5,{ }^{38,39}$ the presence of $\mathrm{NO}$ increases $\mathrm{N}_{2} \mathrm{O}$ decomposition rates. This "catalytic" effect of $\mathrm{NO}$ on $\mathrm{N}_{2} \mathrm{O}$ decomposition rates is consistent with the NO-mediated oxygen removal 
pathways proposed here for NO decomposition, which render $\mathrm{Cu}$ dimers sites reducible and available for redox catalytic turnovers. The transient kinetic measurements proposed here and a companion study of steady-state NO decomposition kinetics ${ }^{26}$ have led to a consistent set of elementary steps that can explain how $\mathrm{NO}$ decomposes into $\mathrm{N}_{2}, \mathrm{~N}_{2} \mathrm{O}, \mathrm{NO}_{2}$, and $\mathrm{O}_{2}$ on $\mathrm{Cu}$-ZSM5 (Figure 12).

\section{Conclusions}

Isothermal and nonisothermal transients were carried out during NO decomposition on $\mathrm{Cu}-$ ZSM5 catalysts in order to examine the nature of the required redox cycles, reactive intermediates, and active sites. These experiments involved the measurements of the dynamic evolution of desorption and reaction products $\left(\mathrm{NO}, \mathrm{N}_{2} \mathrm{O}, \mathrm{NO}_{2}, \mathrm{~N}_{2}\right.$, and $\mathrm{O}_{2}$ ) during reaction in order to obtain information about the mechanism of $\mathrm{NO}$ decomposition. $\mathrm{N}_{2}$ formation rates were proportional to the number of reduced centers $\left\{\mathrm{Cu}^{+}-\square-\mathrm{Cu}^{+}\right\}^{2+}$, and they decreased as the number of these centers decreased during a switch from $\mathrm{He}$ to $0.464 \% \mathrm{NO} / \mathrm{He}$ streams. An isothermal switch from $1 \% \mathrm{NO} / \mathrm{He}$ to $\mathrm{He}$ at $673 \mathrm{~K}$ led to an increase in net $\mathrm{O}_{2}$ formation rates immediately after the switch, indicating that $\mathrm{NO}$ mediates the removal of oxygen from nonvicinal $\left\{\mathrm{Cu}^{2+}-\mathrm{O}^{2-}-\mathrm{Cu}^{2+}\right\}^{2+}$ dimers via the formation of $\mathrm{NO}_{2} *$ and $\mathrm{NO}_{3} *$ species. These species are also intermediates in the established quasi-equilibrium between $\mathrm{NO}, \mathrm{O}_{2}$, and $\mathrm{NO}_{2}$. $\mathrm{NO}_{3} *$ species are stable up to $\sim 573 \mathrm{~K}$ but decompose into $\mathrm{NO}$ and $\mathrm{O}_{2}$ at higher temperatures, thus providing rapid pathways for $\mathrm{O}_{2}$ formation, which, in contrast with recombinative desorption steps, do not require vicinal $\left\{\mathrm{Cu}^{2+}-\mathrm{O}^{2-}-\mathrm{Cu}^{2+}\right\}^{2+}$ dimers.

These findings are consistent with some of the previously reported mechanistic details for this reaction, but they provide a more complete picture than previously available, including the critical oxygen removal pathways, previously attributed to recombinative desorption. The proposed sequence of elementary steps contains as an intrinsic component the pathways required for the decomposition of $\mathrm{N}_{2} \mathrm{O}$, which occurs as a sequential reaction during $\mathrm{NO}$ decomposition.

Acknowledgment. B.M. acknowledges a grant from $\mathrm{CF}$ Miljöfonden and P.D. a grant from the French Foreign Affairs Ministry under the "Programme Lavoisier". D.K.L. acknowledges the support of the Korea Science and Engineering Foundation (KOSEF).

\section{References and Notes}

(1) Iwamoto, M.; Yokoo, S.; Sakai, K.; Kawaga, S. J. Chem. Soc., Faraday Trans. 1981, 77, 1629.
(2) Iwamoto, M.; Furukawa, H.; Mine, Y.; Uemura, F.; Mikuriya, S.; Kagawa, S. J. Chem. Soc., Chem. Commun. 1986, 16, 1272.

(3) Iwamoto, M.; Yahiro, H.; Mine, Y.; Kagawa, S. Chem. Lett. 1989, $2,213$.

(4) Iwamoto, M.; Yahiro, H.; Tanda, K.; Mizuno, N.; Mine, Y.; Kagawa, S. J. Phys. Chem. 1991, 95, 3727.

(5) Iwamoto, M.; Yahiro, H.; Mizuno, N.; Zhang, W. X.; Mine, Y.; Furukawa, H.; Kagawa, S. J. Phys. Chem. 1992, 96, 9360.

(6) Beutel, T.; Sarkany, J.; Lei, G. D.; Yan, J. Y.; Sachtler, W. M. H. J. Phys. Chem. 1996, 100, 845.

(7) Lei, G. D.; Adelman, B. J.; Sarkany, J.; Sachtler, W. M. H. Appl. Catal. B 1995, 5, 245.

(8) Li, Y.; Hall, W. K. J. Catal. 1991, 129, 202.

(9) Schay, Z.; Guczi, L. Catal. Today 1993, 17, 175. 347.

(10) Schay, Z.; Kiricsi, I.; Guczi, L. Stud. Surface Sci. Catal. 1998, 116 ,

(11) Schay, Z.; Knozinger, H.; Guczi, L.; Pal-Borbely, G. Appl. Catal. B 1998, 18, 263 .

(12) Konduru, M. V.; Chuang, S. S. C. J. Phys. Chem. B 1999, 103, 5802 .

(13) Spoto, G.; Zecchina, A.; Bordiga, S.; Ricchiardi, G.; Martra, G.; Leofanti, G.; Petrini, G. Appl. Catal. B 1994, 3, 151.

(14) Giamello, E.; Murphy, D.; Magnacca, G.; Shioya, Y.; Nomura, T.; Anpo, M. J. Catal. 1992, 136, 510.

(15) Valyon, J.; Hall, W. K. J. Phys. Chem. 1993, 97, 1204

(16) Aylor, A. W.; Larsen, S. C.; Reimer, J. A.; Bell, A. T. J. Catal. $1995,157,592$

(17) Konduru, M. V.; Chuang, S. S. C. J. Catal. 1999, 187, 436.

(18) Konduru, M. V.; Chuang, S. S. C. J. Catal. 2000, 196, 271.

(19) Jang, H.-J.; Hall, W. K.; d'Itri, J. L. J. Phys. Chem. 1996, 100, 9416.

(20) Li, Y.; Armor, J. N. Appl. Catal. 1991, 76, L1.

(21) Adelman, B. J.; Lei, G. D.; Sachtler, W. M. H. Catal. Lett. 1994, 28,119 .

(22) Chang, Y.; McCarty, J. G. J. Catal. 1997, 165, 1.

(23) Gervasini, A. Appl. Catal. B 1997, 14, 147.

(24) Valyon, J.; Hall, W. K. J. Catal. 1993, 143, 520.

(25) Trout, B. L.; Chakraborty, A. K.; Bell, A. T. J. Phys. Chem. 1996, 100,17582 .

(26) Moden, B.; Da Costa, P.; Fonfe, B.; Lee, D. K.; Iglesia, E. J. Catal. 2002, 209, 75 .

(27) Da Costa, P.; Moden, B.; Meitzner, G. D.; Lee, D. K.; Iglesia, E. Phys. Chem. Chem. Phys., in press.

(28) Boudart, M.; Djega-Mariadassou, G. In Kinetics of Heterogeneous Catalytic Reactions; Princeton University Press: Princeton, NJ, 1984.

(29) Petunchi, J. O.; Hall, W. K. Appl. Catal. B 1993, 2, L17.

(30) Shelef, M.; Montreuil, C. N.; Jen, H. W. Catal. Lett. 1994, 26, 277 .

(31) Lintz, H. G.; Turek, T. Catal. Lett. 1995, 30, 313.

(32) Turek, T. Appl. Catal. B 1996, 9, 201.

(33) Turek, T. J. Catal. 1998, 174, 98.

(34) Ciambelli, P.; Di Benedetto, A.; Garufi, E.; Pirone, R.; Russo, G. J. Catal. 1998, 175, 161.

(35) Kapteijn, F.; Marban, G.; Rodriguez-Mirasol, J.; Moulijn, J. A. J. Catal. 1997, 167, 256.

(36) Fanson, P. T.; Stradt, M. W.; Delgass, W. N.; Lauterbach, J. Catal. Lett. 2001, 77, 15.

(37) El-Malki, El-M.; van Santen, R. A.; Sachtler, W. M. H. J. Catal. 2000, 196, 212

(38) Sang, C.; Lund, C. R. F. Catal. Lett. 2001, 73, 73.

(39) Mul, G.; Perez-Ramirez, J.; Kapteijn, F.; Moulijn, J. A. Catal. Lett. 2001, 77, 7 . 